Stabilization Through Institutionalization?: Institutionalization of External Relations as a Success Factor in the Reform Process

\title{
Joanna Stryjek
}

SGH Warsaw School of Economics, Aleje Niepodległości 162, 02-554 Warsaw, Poland joanna.stryjek@sgh.waw.pl

$\Gamma$ crossef $h t t p: / / d x . d o i . o r g / 10.5755 /$ j01.eis.0.11.18410

The paper aims to answer the question why the process of institutionalization of the EU's external relations with its six neighboring countries, representing the Eastern dimension of European Neighborhood Policy (i.e., Armenia, Azerbaijan, Belarus, Georgia, Moldova and Ukraine), has failed to perform its stabilization role. The study is analytical and descriptive in nature. Its results indicate three reasons for which the aforementioned institutionalization process has not been successful, and thus - the EU's neighborhood has become even more unstable than it was over a decade ago. The first reason is rooted in the applied integration model. The model expected the EU's neighbors to undergo deep reforms, without offering them the EU membership 'reward'. In this regard, the EU's offer not only failed to meet the expectations of the neighbors in question, but also appeared to be partly misunderstood. In consequence, the Eastern ENP countries considered the decision on their potential EU membership to be exclusively political, as well as underestimated the importance of the previously agreed reforms. As regards the second reason for the unsuccessful development of the institutionalization process, the Eastern ENP countries found it very difficult to reach a high level of 'embeddedness' of the transferred formal institutions in their socio-economic environment. Finally, the institutionalization process has also faced difficulties due to the geopolitical rivalry between the EU and Russia over the region. The actions and policies undertaken by Russia not only influenced the (political and economic) decisions of the EU's Eastern neighbors, but also clearly showed that the institutionalization of their relations with the EU neither provided for them protection nor guaranteed defense. According to the presented theoretical approach, this serves as an explanations why the stabilization function of the institutionalization process was not able to perform its role.

KEYWORDS: ENP, Eastern Partnership, European Union, institutionalization, Europeanization, democratization, democracy promotion, stabilization, transition.

\section{Abstract}

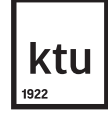

European Integration Studies No. 11 / 2017

pp. $233-243$

DOI 10.5755/j01.eis.0.11.18410

(c) Kaunas University of Technology 
This paper examines the institutionalization of the EU's external relations with its six neighboring countries, currently covered by the Eastern Partnership (EaP) initiative under the EU's European Neighborhood Policy (ENP) - i.e., Armenia, Azerbaijan, Belarus, Georgia, Moldova and Ukraine. The concept of institutionalization of international relations refers to a wide range of theoretical approaches where scholars' emphasis varies from the crude rational-choice approach, which concentrates on the choices of a human agent, to the historical institutionalist approach, which focuses more on the constraints imposed on actors within specific historical contexts. When it comes to international relations, the institutionalization process is supposed to perform three main functions: (1) stabilization function, (2) legitimation function, and (3) integration function (Kukutka, 1988, Kukutka 2000). For the purpose of this study, the stabilization function of the institutionalization process needs to be given particular attention. ${ }^{1}$ The function involves the creation of protection and the guarantee of defense, by means of which the interests of international actors (i.e., states, regional integration groups, international organizations) are to be balanced and stabilized. What is more, it is important for the institutionalization process to confirm the equality of rights and the sovereign equity of the involved states. In the context of this paper, it is also important to bear in mind that the stabilization and integration functions of the institutionalization process are interrelated. This is because the process contributes both to closer cooperation and deeper (political and/or economic) interdependence of the actors involved; in turn, the greater interdependence is expected to contribute to the increase in political and economic stability, and thus - security.

The European Neighborhood Policy strategy paper was presented on 12 May 2004 (European Commission, 2004), that is, almost simultaneously with the biggest enlargement of the EU in its history, which took place on 1 May 2004. The time coordination between these two events reflected, to a large extent, the EU's concerns about the tensions on its newly created Eastern border. What is more, the EU enlargement was preceded by the development of a new security strategy (Council of the European Union, 2003). Although the strategy emphasized Europe's exceptional security:

"Europe has never been so prosperous, so secure nor so free. The violence of the first half of the 20th Century has given way to a period of peace and stability unprecedented in European history" (Council of the European Union, 2003),

at the same time it expressed concerns about the influence of the enlargement process on the political problems in the EU's Eastern neighborhood:

"It is not in our interest that enlargement should create new dividing lines in Europe. We need to extend the benefits of economic and political cooperation to our neighbors in the East while tackling political problems there" (Council of the European Union, 2003).

For the reasons laid down in the security strategy, the stabilization role has been always of high importance in the process of institutionalization of the EU's external relations with its new Eastern neighbors. However, despite the EU's awareness of the aforementioned problems, as well as the actions undertaken to solve them (specifically including the European Neighborhood Policy), the institutionalization process turned insufficient to develop a stable and secure neighborhood. The results of the process were completely opposite to expectations, as the EU's presence in the (historically) Russian 'sphere of influence' became a source of new tensions and conflicts in the region.

The article is analytical and descriptive in nature, i.e., it should be regarded as an analytical contribution rather than a study based on primary research. The aim of the article is to analyze

1 For description of the other two functions see J. Kukutka $(1988 ; 2000)$. 
the external relations of the EU with its Eastern neighbors from the point of view of the (expected) stabilization role of the institutionalization process. The theoretical background for the analysis is drawn from the literature on the functions of the international relations' institutionalization process (Kukutka 1988, 2000). The analysis focuses on the integration model applied by the $\mathrm{EU}$, the level of 'emdeddedness' of the transferred formal institutions into their socio-economic environment of the Eastern ENP countries, as well as the problem of geopolitical rivalry between the EU and Russia in their common neighborhood. Within the context of the aforementioned problems, the study aims to answer the question why the institutionalization of the EU's external relations with the Eastern neighboring countries has failed to perform its stabilization role.

The article is structured as follows. First, the theoretical background for the institutionalization process is provided as well as the historical development of the process is discussed. In what follows, the analysis of the ENP as an instrument for institutionalization of the EU's external relations with its Eastern neighbors is presented. Next, the stability and security problems related to the conflicting interests of the EU and Russia in their common neighborhood are traced. Conclusions follow.

The process of institutionalization of international relations has its origin in the need to regulate and perpetuate desirable actions and interactions of individual actors on the international stage, i.e., states, regional integration groups and international organizations. In a historical perspective, there are four main streams of the institutionalization process (the description of the streams is based on the works of Kukułka, 1988; 2000). The first stream covers institutions, norms and diplomatic procedures, which were created in relation to the international empiricism. Its development led to the creation of a hierarchical diplomatic staff, having specific privileges and immunities as well as applying specific ceremonial in mutual interstate relations. In what followed, new ways and forms of the diplomatic dialogue were developed by the states. Since 1648 (the Peace of Westphalia) the dialogue has been held at the international congresses and conferences.

The second stream of the institutionalization process covers the creation and dissemination of international organizations, which took place after 1815. The development of international organizations reflected the desire to deepen multilateral cooperation and create such international order that could be accepted by the (existing at that time) community of states.

As regards the third stream of the institutionalization process, it includes so-called sectoral institutionalization, that is, the development of states' cooperation in specific areas (sectors), for instance, in the area of security, culture, etc. And finally, the last of the aforementioned streams covers the creation of interstate communities (regional integration groups), which took place in the second half of the XX century. The states belonging to the interstate communities agreed to undertake a long lasting, deep and multilevel cooperation. The best example of such cooperation constituted the European Communities, which originally comprised of the European Economic Community, the European Coal and Steel Community, and the European Atomic Energy Community (later on, the European Communities evolved into the European Union).

Countries belonging to regional integration groups not only are institutionalized within their group, but also, as the group's members, they develop (and thus - institutionalize) external relations with third countries. In case of the European Union, the relations of its members with third countries (or their groups) are being institutionalized in many different ways. This differentiation can be seen even within the group of the EU's neighbors.

The European Neighborhood Policy serves as the main instrument for institutionalization of EU's external relations with a group of its Southern and Eastern neighboring countries (which are
The institutionalization of international relations: a historical perspective and a theoretical background 
Figure 1

Concentric circles model: institutionalization processes and Europeanization of the EU's neighborhood

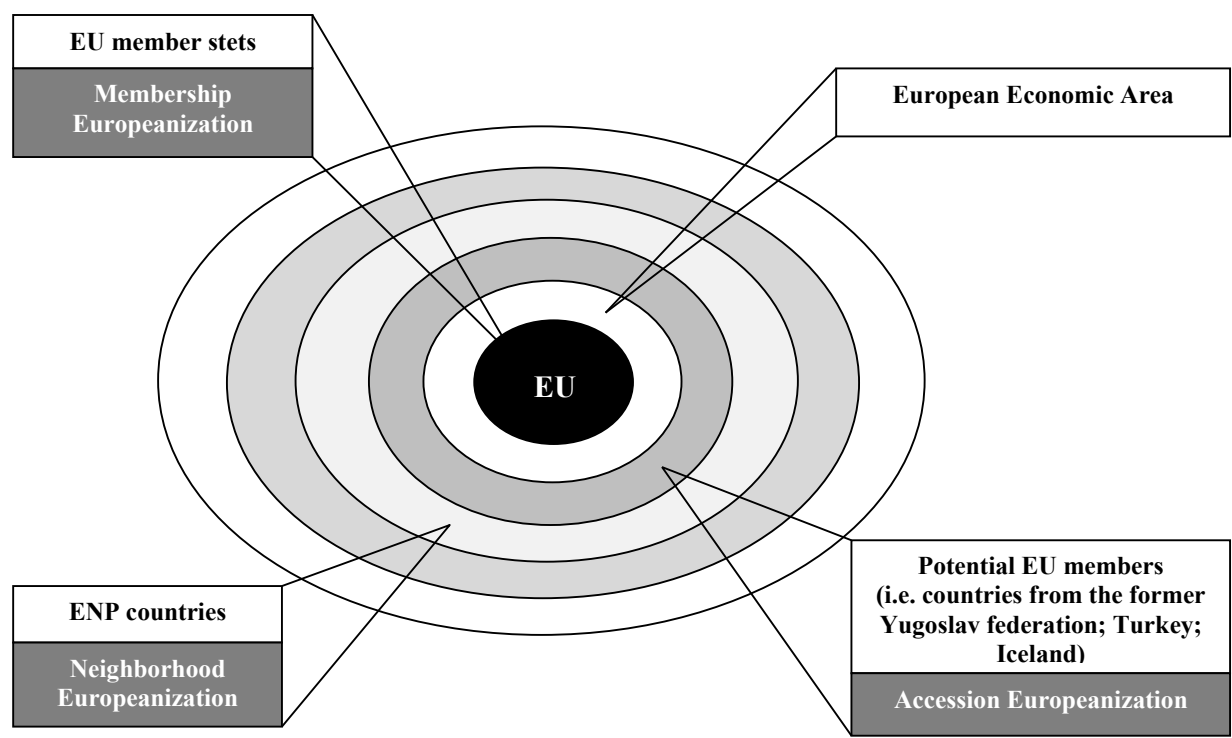

listed below). In case of the other EU's neighbors, the institutionalization processes have been developed on different bases (and thus - in different ways). This can be clearly illustrated by the concentric circles model. ${ }^{2}$ The EU, governed by its 'acquis communautaire', constitutes the core (i.e., the first circle) of the model, and the other circles reflect the following groups of countries (Moga, 2013; see Figure 1):

- The second circle represents the European Economic Area, consisting of the EU member states and the neighboring countries that belong to the European Free Trade Association (i.e., Norway, Iceland and Lichtenstein); the aforementioned group of the EU's neighbors takes part in its internal market.

- The third circle reflects the states that are subject to the potential enlargement process - i.e., the counties from the former Yugoslav federation as well as Turkey and Iceland.

- The forth circle represents all the countries covered by the ENP, i.e., the EU's neighbors with the East (Armenia, Azerbaijan, Belarus, Georgia, Moldova, Ukraine), and the EU's Southern neighbors (Algeria, Egypt, Israel, Jordan, Lebanon, Libya, Morocco, Palestinian National Authority, Syria, Tunisia).

- The fifth and the following circles represent other (numerous) countries in case of which the process of institutionalization of international relations with the $\mathrm{EU}$ is being developed.

Despite the fact that the processes of institutionalization of the EU's relations with third countries shows differences between the individual groups of neighbors, they de facto head the same direction, that is, the processes lead to Europeanization of the neighbors in question. For this reason, the circles distinguished in the concentric circles model (for the purpose to explain the EU's institutionalization processes) can be also related to the studies on Europeanization (Figure 1).

The concept of Europeanization was introduced and then gradually examined on various policy areas through the 1990s (see e.g. Ladrech, 1994; Andersen, 1995; Radaelli, 1997; Harmsen,

2 The description of the concentric circles model is based on T. Moga (2013). 
1999; Agh, 1999). By now, it has become a widely deployed research approach amongst scholars from International Relations and European Studies, and it has developed into three streams of research (Gawrich, Melnykovska, Schweickert, 2010):

- The first stream includes so-called 'membership Europeanization'; it describes the EU's impact on its member states (and relates to the first circle of the concentric circles model - see Figure 1);

- The second stream covers 'accession Europeanization', that is, it concerns countries with a clear EU membership perspective (and relates to the third circle of the concentric circles model);

- The last stream is called 'neighborhood Europeanization'; it includes the Eastern and Southern neighbors of the EU, who are covered by the ENP and have no (official) accession perspective (the stream relates to the forth circle of the concentric circles model).

In the context of this paper, the process of neighborhood Europeanization is of great importance. It consists in the transmission of the EU's policy and institutional models (i.e., formal institutions ${ }^{3}$ ) to its neighboring countries. There are two interrelated factors that are particularly decisive in the successful transfer of formal institutions to the ENP countries. First, the domestic actors of the recipient country need to consider the adoption of the institutions (institutional model): (1) appropriate, (2) useful for pursuing their particular interests, or (3) as a means to acquiring a more legitimate role in the international community (Celata, Coletti, 2016). Second, the transferred institutions have to be not only de jure (i.e., formally) integrated into the formal institutional framework of the recipient country but also de facto embedded into the informal socio-economic institutions of the recipient society (compare to: Martens at al., 2001). According to Douglass North's institutional theory (1990), the successful 'embeddedness' of (formal institutional) reforms in the wider socio-economic environment is more likely to take place when informal institutions in the country of origin (of the transferred formal institution/ institutional model) show similarities to the informal institutions of the recipient country.

The process of institutionalization of the EU's external relations with the countries currently covered by the Eastern dimension of the European Neighborhood Policy was launched in 1990s, that is, much earlier than the ENP was implemented. The development of the process was closely related to the decision on extending European Union membership to the Central and Eastern European countries (CEECS). The decision was accompanied by the need to develop new instruments for cooperation with the future EU neighbors in order to increase the stability in the new neighborhood. At that time, the UE's bilateral relations with almost all the (potential) Eastern neighbors were shaped by the Partnership and Cooperation Agreements ${ }^{4}$ (PCAs). The main objectives of cooperation, laid down in the agreements, included (Nowak, 2011; Stryjek, 2015): (1) development of (close) political relations; (2) support for the development of democracy in the neighboring countries, as well as the economic development of their economies in order to complete the process of transition of these countries into market economies; (3) promotion of trade, investment and harmonious economic relations in order to support sustainable economic development; (4) provision of frameworks for legislative, financial, scientific, technological, civil, social and cultural cooperation. Since the conclusion of the PCAs, the EU practices and

3 The division of institutions into formal and informal refers to D. North's institutional theory (1990), defining institutions as the formal and informal rules, laws, regulations, contracts and agreements that guide people's behaviour.

4 The Partnership and Cooperation Agreements were signed in the period 1998-1999. They were concluded between the European Communities and their member states, of the one part, and - respectively - Armenia, Azerbaijan, Georgia, Moldova and Ukraine, of the other part.

\section{ENP as an instrument for institutionalization of the EU's external relations with its Eastern neighbors}


institutional arrangements have served as a benchmark for policy change in the region (Langbein \& Börzel, 2013). However, it is important to emphasize that in the early 1990s (i.e., before the PCAs were concluded) the EU's participation in the (economic and political) transformation of the countries in question was minimal. It was just the opposite in the CEECs, in case of which the EU has been taking part in the transformation processes since their beginning, and thus influenced newly shaped institutions and political elites. In the Eastern ENP countries the new institutions and political elites were formed without the EU's participation. This should be regarded as one of the reasons for which the cooperation between the EU and the Eastern ENP countries was more difficult than in case of the CEECs (Knothe, 2017).

As it was mentioned before, the ENP was launched almost immediately after the EU's enlargement to the East in 2004. The policy - while being designed - was clearly modeled on the EU's experience coming from the enlargement processes (Kelly, 2006; Leino \& Petrov, 2009). This included in particular numerous economic and political reforms to be made by the neighboring states. However, the important thing is that the ENP countries have never been promised the membership in the European Union (i.e., the bilateral agreements signed by the EU with these countries did not contain an explicit mention of the membership perspective). In other words, the EU's offer included almost everything that was previously expected from the CEECs except the EU membership 'reward'.

In the context of the above, the decision of the European Commission to adapt enlargement policies in the newly shaped neighborhood could be theoretically interpreted in two ways. First, the integration model could have been perceived as the best possible and, to a certain degree, tested solution or - second - there might have been an intention to (unofficially) leave the door open to the EU membership. However, even if there was a 'hidden' intention not to exclude the EU membership possibility, the unsatisfactory development of the ENP (i.e., slow reform processes) made a potential further EU's enlargement to the East impossible. ${ }^{5}$ This was at least several times clearly stated by the politicians of the EU member states. For instances, the German chancellor Angela Merkel, while explaining the aims behind the development of the Eastern Partnership initiative, stated that "the Eastern Partnership is not an instrument for enlargement of the European Union, but it is an instrument of rapprochement with the European Union" (statement made at the Eastern Partnership Riga Summit in 2015 - Maurice, 2015). Hence, the decision to adapt enlargement policies in the Eastern ENP countries should be perceived mainly as a willingness to implement solutions with which the EU was familiar, and most probably considered them to be the best option. This is all the more so when taking into consideration that - over the years of its existence - the European Union (and previously European Communities) has gone through many enlargement processes. Although each of the enlargements was different, they contributed to the creation (and then improvement) of a certain procedure for the preparation of a given country for the EU membership. Additionally, they made the EU get used to look at its neighbors through the enlargement lens and - in consequence - expect them to be willing to share the same values. This was also true for the Eastern ENP countries. In other words, the historical context serves as an explanation for the decision on the integration model between the parties in question.

The EU's tendency to reproduce its integration experience in the ENP countries has been analyzed in numerous studies (Bicchi, 2006; Bauer et al., 2007; Lavenex, 2008; Schimmelfennig, 2007; Barbé et al., 2009; Boerzel, 2011; Lightfoot et al., 2016). At the same time, a low (or even minimal) degree of Europeanization has been observed in the countries covered by the neighborhood

5 Additionally, the EU's enlargement of 2004 made it clear the EU cannot enlarge forever, simply due to the limits of its institutions effectiveness. 
policy (Van Hüllen 2012; Delcour 2013). This low degree of Europeanization constitutes - to a large extent - a consequence of the integration strategy implemented by the $\mathrm{EU}$ in the region. As it was already mentioned, the EU's expectations that the ENP countries would undertake reform efforts similar to those that were undertaken by the CEECs (but without being offered the prospect of membership) was unlikely to be met. Firstly, the Eastern neighbors did not feel motivated enough to carry out such deep reforms, and this was related not only to the lack of the membership perspective. In the opinion of the aforementioned neighbors, their potential EU membership was dependent entirely on the political decision of the EU member states (and not on the progress in reforms implementations), and thus the decision seemed possible to be taken at any time (Knothe, 2017). From this point of view, the ruling elites in the EU's partner countries simply underestimated the importance of reforms. Moreover, even if the countries decided to implement reforms, the new solutions were often only de jure integrated into the formal institutional framework, and not de facto embedded in a wider socio-economic environment.

Apart from the above, the lack of the membership perspective made the potential effects of the integration strategy more uncertain. The countries that were offered the prospect of membership could (at least approximately) estimate the effects of the integration process on the basis of data concerning previous enlargements. The ENP countries did not have such possibility, as they were covered by the policy which was implemented for the first time. Moreover, due to the uncertainty, the Eastern ENP countries have been always opened to and encouraged cooperation with other international actors. This is visible especially in trade, which constituted one of the most important components of the economic integration between the EU and the ENP states. ${ }^{6}$ For instance, while analyzing the trade exchange of the Eastern ENP countries with all world partners, growth rate trends show an increasing role for BRICS economies (i.e., Brazil, Russia, India, China, South Africa) for both imports and exports (Kallioras \& Pinna, 2017).

The trade gains and other economic benefits of the EU-ENP countries cooperation have been always of great importance, as they were supposed to encourage the governing elites of the neighboring countries to implement political reforms. In general, the ENP originated in the assumption that external liberalization, coupled with domestic economic reforms, should have been given priority over political changes. It was argued that the provision of basic needs was most important for respective populations, and that political freedoms would follow suit (Tarnawski, 2014; see as well Stryjek, 2016). However, as practice suggests, liberalization of the economy, as well as the financial support provided by the EU, proved to be ineffective without a system of democratic control (Tarnawski, 2014). Both the military conflict in Ukraine and the uprisings and upheavals in the Middle East and North African region (i.e., the so-called Arab Spring) can serve as an evidence that political reforms are as important as the economic ones in view of stability of the EU's neighborhood.

The EU's socio-economic model is built on the premise that democracy is a necessary condition for its functioning and development. For this reason, the EU placed great emphasis on upholding and promoting democratic values and practices in its neighborhood. The EU's expectations in this regard were based on its successful experience in contributing to the consolidation of democracy in CEECs (Buscaneanu, 2015). However, unexpectedly, the promotion of democratic values in the Eastern ENP countries appeared to be very difficult. Firstly, most of the countries

6 At the time when the neighbourhood policy was introduced, the scope of potential economic integration models for the EU and its neighbours ranged from models incorporating bilateral deep free trade or multilateral simple free trade arrangements to models incorporating a stake in the common market, with its four freedoms (or three freedoms, i.e., with the exclusion of the freedom of labour), which was seen as the most attractive economic offer (Gawrich, Melnykovska, Schweickert, 2010). 
have already developed oligarchic institutions, and the governing elites wanted to preserve the oligarchic systems. In this respect, the gains coming from the economic cooperation with the EU, which were supposed to encourage the states' authorities to carry out political reforms, were definitely not motivating enough. Secondly, as it was previously explained, the most valued EU offer - i.e., the possibility of EU membership - was not on the table. And thirdly, according to some scholars, successful democracy promotion was difficult also because the ENP lacked (and still lacks) consistency in democracy-related areas. For instance, Tom Theuns argues that democracy promotion is in conflict with some of the other ENP goals, such as market liberalization, private sector development and trade policy reforms (2016). According to his suggestions, democratization could be coherently promoted in the ENP countries in two ways: (1) by delimiting the policy to unilateral transfers conditional on democratization alone, or (2) by offering EU membership to the countries covered by the neighborhood policy.

Conflicting interests of the EU and Russia in their common neighborhood
A successful institutionalization of the EU's relations with the Eastern ENP countries and, in particular, the stabilization function of the institutionalization process have been highly dependent on the actions and policies undertaken by Russia. As the EU's Eastern neighbors belong to the so-called post-Soviet space, Russia - being another important regional player - has always had its own concept for the policy change in the region (Averre, 2009). No need to explain that the concept was (and still is) in contradiction with the policy developed by the EU. Its realization thwarted not only the economic integration between the EU and the Eastern ENP countries but also the democratic development of the EU's Eastern neighbors (Langbein \& Börzel, 2013).

In addition to the above, Russia showed tendency to increase tensions that appeared on (or close to) its borders, so that they turned into military conflicts. It can be even said that Russia's military interventions (or destabilizing influence) in the region constituted an important element of its external policy (for examples of the Russian destabilizing influence in the region see e.g. Falkowski \& Stryjek, 2016). These actions bought various effects. In the context of the problems discussed in this paper, they clearly showed that the institutionalization of the EU's relations with the Eastern ENP countries neither created protection nor guaranteed defense in the EU's neighborhood. For instance, the 2008 military conflict between Russia and Georgia showed that the ENP countries - in case of being attacked by Russia - most probably would have to face the problem (i.e., defend themselves) alone. As the countries are small and their military potentials are low, the fear of armed conflict with Russia, in some cases, negatively influenced their decisions on deepening cooperation with the EU.

Taking into consideration the above arguments it becomes clear that the ENP not only failed in providing stability and security in the EU's Eastern neighborhood, but also constituted an additional destabilizing factor itself (as the Eastern ENP countries belong to the historically Russian 'sphere of influence'). Although the EU's cooperation strategy towards the aforementioned neighbors should not be taken as the sole or even key cause of the security problems in and around the EU's Eastern frontier, both the ENP and then the Eastern Partnership have played an important role in their developments (Dangerfield, 2016). As Ademmer et al. (2016) clearly explains, Moscow's objections to the EU's policies date back to the beginning of 2000s, when the Color Revolutions in Georgia (2003) and Ukraine (2004) took place and thus signaled to Russia the possible loss of its influence in its Western neighborhood. Afterwards, Russia's concerns kept raising because of the further actions and policies undertaken by the $\mathrm{EU}$ :

'The EaP, in particular, signaled a shift toward hard-law integration with the EU that was interpreted in Russia as a constraint to its own policies in the region (...). The competition for influence over their "contested neighborhood" reached its climax with the imminent signing of an Association 
Agreement between the EU and Ukraine, culminating in a chain of events that started with mass protests and led to the annexation of Crimea by Russia and, with the support of Russia, to the war in Eastern Ukraine' (Ademmer et al., 2016).

As a result of the geopolitical rivalry between the EU and Russia over their common neighborhood, domestic reform processes in the Eastern ENP countries were de facto shaped by both the aforementioned actors. In this regard, the EU definitely overestimated its ability to influence domestic changes in the ENP countries, as well as to ensure stability in its Eastern neighborhood. However, it needs to be emphasized that the effectiveness of implementation of the EU's institutionalization strategy was low not only because of the actions and policies undertaken by Russia, but also due to the specificity of the neighboring countries' economies (i.e., especially the lack of functional legal system and/or capacity to implement desirable reforms - see Dragneva \& Wolczuk, 2011; Ademmer et al., 2016) and the (previously discussed) insufficient incentives for reforms.

When the ENP was launched, the conditions for further institutionalization of the EU's external relation with its Eastern neighbors seemed to be, in many respects, favorable. The EU had extensive experience in cooperation and integration with countries representing lower level of development. Apart from that, the EU member states included, inter alia, the group of CEECs which undergone successful (political and economic) transformation, significantly reducing the development gap that separated them from their Western partners. Moreover, one of the most desirable effects of the institutionalization process - i.e., the stability of the region - was both in the interest of the EU and its neighbors. And finally, the EU created financial instruments to officially support reform processes in the neighboring countries.

All the aforementioned circumstances created a situation where one could expect a successful institutionalization of the EU's relations with the neighboring countries, including in particular proper performance of the stabilization function of the institutionalization process. However, it turned to be just the opposite, that is, along with the passage of time, the UE's neighborhood became even more unstable.

The article indicates three reasons for which the institutionalization of the EU's external relations with the Eastern ENP countries has failed to perform its stabilization role:

- The first one is rooted in the applied integration model, and specifically - in the EU's expectation that the neighboring countries would be satisfied with sharing with the EU 'all but institutions' (Prodi, 2002). As it was explained before, the Eastern ENP countries perceived their potential EU membership as an exclusively political decision. For this reason, on the one hand, the countries were disappointed with the EU's offer and expected it to change. And on the other hand, they underestimated the importance of the reform process for their stable and prosperous development.

- The second reason was related to a very low level of 'embeddedness' of the transferred formal institutions into the socio-economic environment of the Eastern ENP states. This was due to considerable differences between informal institutions in the recipient countries and the countries of origin. In other words, even if the Eastern ENP countries undertook efforts to implement reforms and transfer formal institutions, the new solutions were often only de jure integrated into the formal institutional framework, and not de facto embedded in a wider socio-economic environment.

- The third reason was related to the geopolitical rivalry between the EU and Russia over their common neighborhood. As Russia showed tendency to increase tensions that appeared on (or close to) its borders and then impose its will through military interventions, some of the ENP 
countries began to fear being attacked by Russia. What is more, Russia's military interventions clearly showed that the institutionalization of the EU's relations with the Eastern ENP countries neither provided for the EU's neighbors protection nor guaranteed defense. In other words, the stabilization function of the institutionalization process was not able to perform its role.

Acknowledgements: This research project has benefited from funding under the Polish "National Science Centre" (NCN) grant titled "European Neighborhood Policy: (multi-level) governance, the reform process and the prospect of enhanced cooperation in the region", OPUS/HS5, decision No. DEC-2013/09/B/HS5/04534.

Ademmer, E., Delcour, L. \& Wolczuk, K. (2016). Beyond geopolitics: exploring the impact of the EU and Russia in the ,contested neighbourhood". Eurasian Geography and Economics, 57(1), 1-18. https://doi. org/10.1080/15387216.2016.1183221

Agh, A. (1999). Europeanization of policy-making in East Central Europe: the Hungarian approach to EU accession. Journal of European Public Policy, 6(5), 839-854.https://doi.org/10.1080/135017699343414 Andersen, S. S. (1995). Europeanization of policy-making. Tidsskrift for samfunnsforskning, 36(4), 495-518.

Averre, D. (2009). Competing Rationalities: Russia, the EU and the ,Shared Neighbourhood". Europe-Asia Studies, 61(10), 1689-1713. https://doi. org/10.1080/09668130903278918

Barbé, E., Costa, O., Herranz, A. et al. (2009). Drawing the Neighbours Closer... to What? Explaining Emerging Patterns of Policy Convergence between the EU and its Neighbours. Cooperation and Conflict, 44(4), 378-399. https://doi.org/10.1177/0010836709344423

Bauer, M. W., Knill, C. \& Pitschel, D. (2007). Differential Europeanization in Eastern Europe: The Impact of Diverse EU Regulatory Governance Patterns, Journal of European Integration. 29(4), 405-423. https://doi.org/10.1080/07036330701502431

Bicchi, F. (2006). ,Our size fits all': normative power Europe and the Mediterranean. Journal of European Public Policy, 13(2), 286-303. https://doi. org/10.1080/13501760500451733

Boerzel, T.A. (2011). When Europe hits ... beyond its borders: Europeanization and the near abroad. Comparative European Politics, 9(4-5), 394-413. https://doi.org/10.1057/cep.2011.8

Buscaneanu, S. (2015). EU Democracy Promotion in Eastern ENP Countries. East European Politics and Societes, 29(1), 248-286. https://doi. org/10.1177/0888325414535430

Celata, F. \& Coletti, R. (2016). Beyond Fortress Europe. Unbounding European Normative Power and the Neighbourhood Policy. Geography Compass, 10(1), 15-24. https://doi.org/10.1111/gec3.12254

Council of the European Union. (2003). A secure Europe in a better world - European Security Strategy. Retrieved May 6, 2017, from https://www.consilium.europa.eu/uedocs/cmsUpload/78367.pdf

Dangerfield, M. V. (2016). Dilemmas of Post-Enlargement Europe: Building an 'Insecurity Zone'? European Integration Studies, No 10, 8-15.

Delcour, L. (2013). Meandering Europeanisation. EU policy instruments and policy convergence in Georgia under the eastern partnership. East European Politics, 29(3), 344-357. https://doi.org/10.1080/2 1599165.2013.807804

Dragneva, R. \& Wolczuk, K. (2011). EU Law Export to the Eastern Neighbourhood. In P. J. Cardwell (ed.) EU External Relations Law and Policy in the Post-Lisbon Era (pp. 217-240). The Hague: T. M. C. Asser Press. https://doi.org/10.1007/978-90-6704-823-1_11

European Commission (2004). Communication of 12 May 2004 entitled 'European Neighbourhood Policy - Strategy paper', COM(2004) 373.

Falkowski, K. \& Stryjek, J. (2016). European Neighbourhood Policy and FDI: Eastern Dimension. In G.C. Pascariu, T.L. Moga, L.M. Simionov (eds.) The Eastern Partnership under strain - time for a rethink? (pp. 188-209). Iași: Editura Universității “Alexadru loan Cuza" lași.

Gawrich, A., Melnykovska, I., Schweickert, R. (2010). Neighbourhood Europeanization through ENP: The Case of Ukraine. Journal of Common Market Studies, 48(5), 1209-1235. https://doi.org/10.1111/ j.1468-5965.2010.02110.x

Harmsen, R. (1999). The Europeanization of national administrations: A comparative study of France and the Netherlands. Governance - An International Journal of Policy and Administration, 12(1), 81-113. https://doi.org/10.1111/0952-1895.00091

Kallioras, D. \& Pinna, A. M (2017). Trade activity between the $\mathrm{EU}$ and its neighbouring countries: 
trends and potential. Tijdschrift voor Economische en Sociale Geografie, 108(1), 36-51. https://doi. org/10.1111/tesg.12193

Kelley, J. (2006). New Wine in Old Wineskins: Promoting Political Reforms through the New European Neighbourhood Policy. Journal of Common Market Studies, 44(1), 29-55. https://doi. org/10.1111/j.1468-5965.2006.00613.x

Knothe, T. (2017). Speach at the conference "Is this the end of the European Neighborhood Policy?", SGH Warsaw School of Economic, 9 May 2017.

Kukutka, J. (1988). Instytucjonalizacja w stosunkach międzynarodowych. In J. Kukułka (ed.), Zmienność i instytucjonalizacja stosunków międzynarodowych. Warszawa: PWN.

Kukułka, J. (2000). Teoria stosunków międzynarodowych. Warszawa: Scholar.

Ladrech, R. (1994). Europeanization of Domestic Politics and Institutions - The Case of France. Journal of Common Market Studies, 32(1), 69-88. https://doi. org/10.1111/j.1468-5965.1994.tb00485.x

Langbein, J. \& Börzel, T. A. (2013). Introduction: Explaining Policy Change in the European Union's Eastern Neighbourhood, Europe-Asia Studies, 65(4), 571580. https://doi.org/10.1080/09668136.2013.766042

Lavenex, S. (2008). A Governance Perspective on the European Neighborhood Policy: Integration Beyond Conditionality? Journal of European Public Policy, 16(6), 938-955. https://doi. org/10.1080/13501760802196879

Leino, P. \& Petrov, R. (2009). Between ,Common Values' and Competing Universals-The Promotion of the EU's Common Values through the European Neighbourhood Policy. European Law Journal, 15(5), 654-671. https://doi.org/10.1111/j.1468-0386.2009.00483.x

Lightfoot, S., Szent-Iványi, B. \& Wolczuk, K. (2016). Mesmerized by Enlargement: The EU's Eastern Neighborhood Policy and New Member State Transition Experience. East European Politics and
Societies and Cultures, 30(3), 664-684. https://doi. org/10.1177/0888325416632041

Martens, B., Mummert, U., Murrell, P. \& Seabright, P. (2001). The institutional economics of foreign aid. Cambridge: Cambridge university press.

Maurice, E. (2015). Ex-Soviet states accept limited EU perspective. Retrieved May 7, 2017, from https://euobserver.com/foreign/128799

Moga, T.L. (2013), Forging Good Societies in the EU's Eastern Neighbourhood. European Journal of Science and Technology, vol. 9, supplement 2, 65-72.

North, D. (1990). Institutions, institutional change and economic performance. Cambridge: Cambridge university press. https://doi.org/10.1017/ CB09780511808678

Prodi, R. (2002). A Wider Europe - A Proximity Policy as the key to stability, speech 02/619 delivered at Sixth ECSA-World Conference, Brussels, 5-6 December 2002.

Radaelli, C. M. (1997). How does Europeanization produce domestic policy change? Corporate tax policy in Italy and the United Kingdom. Comparative Political Studies, 30(5), 553-575. https://doi. org/10.1177/0010414097030005002

Stryjek, J. (2015). Inter-regional cooperation and FDI flow: one step too far? - preconditions and prospects, Yearbook of the Institute of East-Central Europe, 13(4), 125-143.

Stryjek, J. (2016), European Neighbourhood Policy and FDI: the Southern Dimension. Yearbook of the Institute of East-Central Europe, 14(6), 49-68.

Theuns, T. (2017). Promoting democracy through economic conditionality in the ENP: a normative critique. Journal of European Integration, 39(3), 287-302. https://doi.org/10.1080/07036337.2016.1263625

Van Hüllen, V. (2012). Europeanisation through cooperation? EU democracy promotion in Morocco and Tunisia. West European Politics, 35(1), 117-134. https://doi.org/10.1080/01402382.2012.631317

\section{STRYJEK JOANNA}

$\mathrm{PhD}$

SGH Warsaw School of Economics

\section{Fields of research interests}

Innovation Policy, National Innovation Systems, Economic and Monetary Union, European Neighbourhood Policy

\section{Address}

Aleje Niepodległości 162, 02-554 Warsaw, Poland E-mail: Joanna.Stryjek@sgh.waw.pl

\section{About the authors}

